\author{
RED MOUN'TAIN G-E-M \\ RESOURCES AREA.
}

(GRA NO. CA-12)

TECHNICAL REPORT

(WSA CA 050-132)
BLM Library

D-653A, Buil diring 50

Denver Foderal Conter

Danver, CO 80225-0047

Contract YA-553-RFP2-1054

Prepared BY

Great Basin GEM Joint Venture

251 Ralston Street

Reno, Nevada 89503

For

\begin{abstract}
Bureau of Land Management
Denver Service Center Building 50, Mailroom Denver Federal Center

Denver, Colorado 80225
\end{abstract}

Final Report

April 22, 1983 


\section{TABLE' OF CONTENTS}

Page

EXECUTIVE SUMMARY $\ldots \ldots \ldots \ldots \ldots \ldots \ldots \ldots \ldots \ldots \ldots \ldots \ldots \ldots$

I. INTRODUCTION $\ldots \ldots \ldots \ldots \ldots \ldots \ldots \ldots \ldots \ldots \ldots \ldots \ldots \ldots \ldots$

II. GEOLOGY .............................. 10

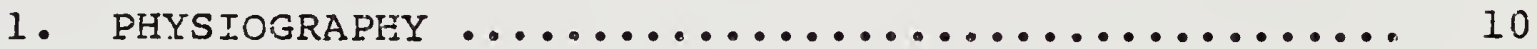

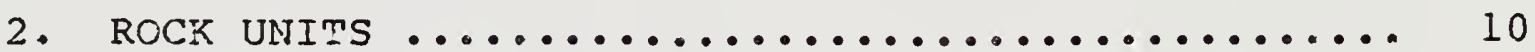

3. STRUCTURAL GEOLOGY AND TECTONICS ............ 11

4. PALECNTOLOGY $\ldots \ldots \ldots \ldots \ldots \ldots \ldots \ldots \ldots \ldots \ldots \ldots \ldots$

5. HISTCRICAL GEOLOGY ................... II

III. ENERGY AND MINERAL RESOURCES ............... 13

A. METALIIC MINERAL RESOURCES $\ldots \ldots \ldots \ldots \ldots \ldots \ldots \ldots$

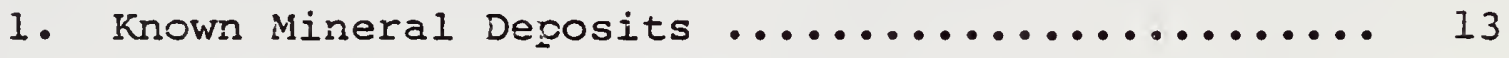

2. Known Prospects, Mineral Occurrences and Mineralized Areas .................... 13

3. Mining Claims ....................... 14

4. Mineral Deposit Types ..................... 14

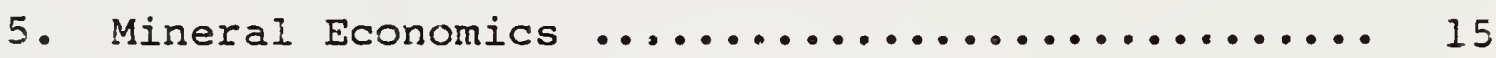

B. NONMETALLIC MINERAI RESOURCES $\ldots \ldots \ldots \ldots \ldots \ldots \ldots . \ldots . \ldots 16$

1. Known Mineral Deposits ................. I6

2. Known Prospects, Mineral Occurrences and Mineralized Areas ................... 17

3. Mining Claims, Leases and Material Sites ...... i7

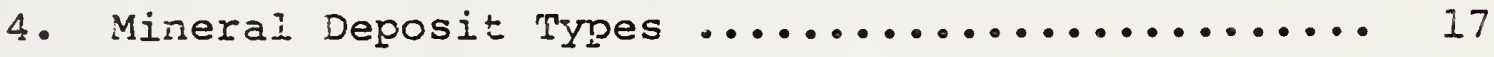

5. Mineral Economics .................. 17 
Table of Contents cont.

Page

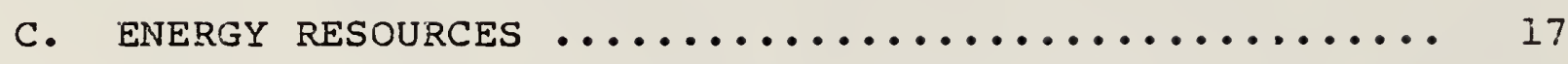

Uranium and Thorium Resources $\ldots \ldots \ldots \ldots \ldots \ldots \ldots . \ldots 17$

1. Known Mineral Deposits ..................... 17

2. Known Prospects, Mineral Occurrences and

Mineralized Areas $. \ldots \ldots \ldots \ldots \ldots \ldots \ldots \ldots \ldots \ldots \ldots . \ldots \ldots$

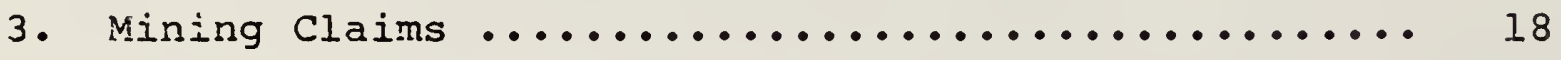

4. Mineral Deposit Types ........................... 18

5. Mineral Economics ........................ 18

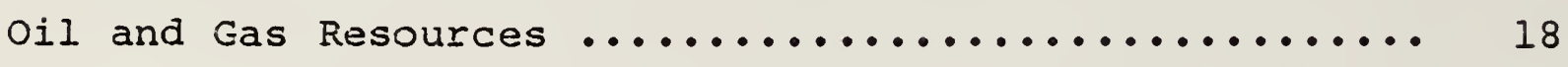

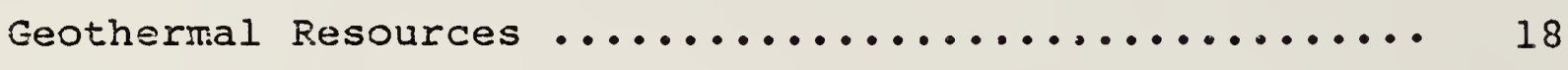

i. Known Geothermal Deposits .................... 18

2. Known Prospects, Geothermal Occurrences, and Geothermal Areas ....................... 18

3. Geothermal Leases $\ldots \ldots \ldots \ldots \ldots \ldots \ldots \ldots \ldots . \ldots . \ldots 18$

4. Geothermal Deposit Types .................... 19

5. Geothermal Economics .................... I9

D. OtHER GECLOGICAL RESOURCES ...................... 19

E. STRATEGiC AND CRITICAL MINERALS AND METALS ....... 20

IV. LAND CLASSIFICATION FOR G-E-M RESOURCES POTENTIAL ... 21

1. LOCATABLE RESOURCES $\ldots \ldots \ldots \ldots \ldots \ldots \ldots \ldots \ldots \ldots \ldots \ldots . \ldots \ldots \ldots$

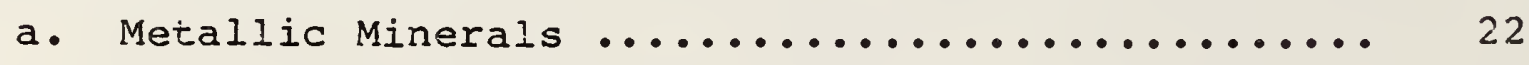

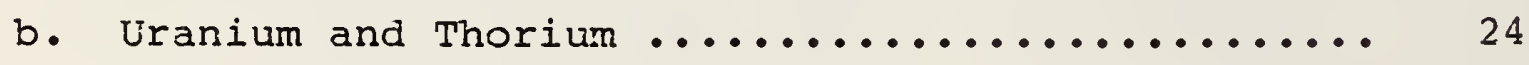

c. Nonmetallic Minerals .................... 24 
Table of Contents cont.

2. LEASABLE RESOURCES $\ldots \ldots \ldots \ldots \ldots \ldots \ldots \ldots \ldots \ldots . \ldots . \ldots . \ldots . \ldots 24$

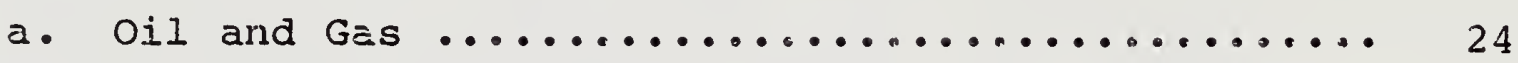

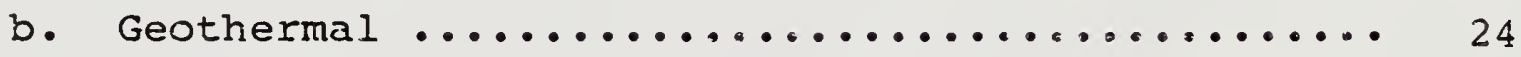

c. Sodium and Potassium ..................... 25

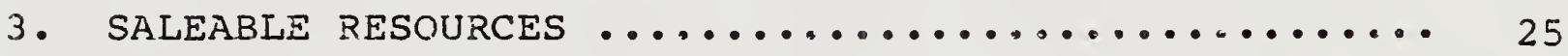

V. RECOMMENDATIONS FOR ADDITIONAI WORK $\ldots \ldots \ldots \ldots \ldots \ldots . . \ldots$

VI. REFERENCES AND SELECMED BIBLIOGRAPHY ........... 27 
Table of Contents cont.

\section{LIST OF ILLUSTRATIONS}

Figure 1 Index Map of Region 3 showing the

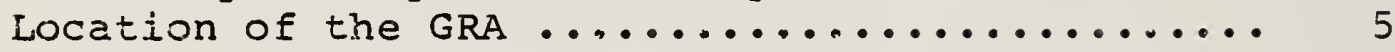

Figure 2 Topographic map of GRA, scale 1:250,000,..... 6

Figure 3 Geologic map of GRA, scale $1: 250,000 \ldots \ldots \ldots . \ldots$

ATTACHMENTS

(At End of Report)

CLAIM AND LEASE MAPS

Patented/Unpatented

Oil and Gas

MINERAL OCCURRENCE AND LAND CLASSIFICATION MAPS (Attached)

Metaliic Minerals

Uranium and Thorium

Nonmetallic Minerals

GeothermaI

LEVEL OF CONFIDENCE SCHEME

CLASSIFICATION SCHEME

MAJOR STRATIGRAPHIC AND TIME DIVISIONS IN USE BY THE U.S. GEOLOGICAI SURVEY 
The Red Mountain GRA includes the towns of Leggett and Cummings in northern Mendocino County, California; it is about fifty miles north of Ukiah. There is one WSA in the GRA: CA 050-132.

Most of the rocks of the GRA are marine sediments of Jurassic to Cretaceous age (about 100 to 190 million years old) including in part the Franciscan Formation. Between two faults is a body of ultrabasic intrusive rocks of unknown age, about three miles by six miles in extent, which contains the nickel-chromiun-cobalt deposits that are the only known mineral resources of the area.

There is no known established mining district in the GRA, but Red Mountain and Little Red Mountain have been known to have chromite deposits for many years, and at least. 100 tons of chrornite ore have been shipped. Drilling by at least three major mining companies over the past thirty years is said to inaicate 30 to 40 million tons of material with about $0.8 \%$ nickel and values in cobalt and chromium. All three are strategic and critical metals.

There are no patented claims in the GRA. There are a great many unpatented claims, essentially covering all unpatented ground in a band about $s$ ix miles long north-south and two miles wide east-west and covering about the central one-third of WSA CA 050-132. They completely cover the rock type that has potential for nickel resources. To the east and west on different rocks there are no claims.

There are no oil and gas, geothermal, or sodium and potassium leases, and no known material sites in the GRA or WSA.

The known nickel-bearing material occurs in three separate areas of the GRA, all classified as having high favorability with a high level of confidence for nickel, cobalt and chromite resources. The edges of all three of these areas extend into WSA CA 050-132, though they lie mostly outside the WSA. The remainder of the midale part of the WSA is classified as having moderate favorability with a low level of confidence for nickel, cobalt and chromite. The eastern, northwestern and southwestern parts are classified as having no known favorability for metallic nineral resources with a very low confidence level.

The entire GRA and WSA are classified as having no known favorability for uranium or thorium resources. There is a very low level of confidence in this classification. The entire wSA has low favorability for nonmetallic minerals, with a low level of confidence in this classification.

The entire GRA and WSA are classified as having no known favorability with a high conficence level for oil and gas, coal, tar sands or shale oil and for sodium and potassium. 
The entire CRA and WSA are classified as having low favorability, with a very low level of confidence, for geothermal resources.

Ar effort should be made to obtain information on the nickel, cobaj.t and chromium resources of the WSA from the U. S. Bureau of Mines and private industry. 
The Red Mountain G-E-M Resources firea (GRA No. CA-12) contains approximately 88,000 acres $(356 \mathrm{sq} \mathrm{km}$ ) and includes the following Wilderress Study Area (WSA):

WSA Name

Red Mountain
WSA Number

$050-132$

The GRA is located in California in the Bureau of Land

Management's (BLM) Eureka Resource Area, Ukiah disirict. Figure I is an index map showing the location of the GRA. The area encompassed is near $39^{\circ} 55^{\prime}$ north latitude, $123^{\circ} 45^{\prime}$ west longitude and includes the following townships:

The areas of the WSAs are on the following U. S. Geological Survey topographic maps:

15-minute:

\section{Legget}

7.5-minute: Noble Butte
Legget
Bell Springs

Tan Oak Park

The nearest town is leggett which is located in the central area of the GRA on U. S. Highway 101. Access to the area is via U. 5. Highway 101 between Piercy and Curmings. Access within the area is by way of numerous unj.mproved roads northeast of Highway 101 and on Mail Rigge Road in the eastern area of the GRA.

Eigure 2 outlines the boundaries of the GRA and the WSA on a topographic base at a scale of $1: 250,000$.

Figure 3 is a geologic map of the GRA and vicinity, also at 1:250,000. At the end of the report, following the Land Classification Maps, is a geologic time scale showing the various geologic eras. periods and epochs by name as they are used in the text, with the corresponding age in years. This is so that the reader who is not familiar with geologic time subdivisions will have a comprehensive reference for the geochronology of events. 
This GRA Report is one of fifty-five reports on the GeologyEnergy-Minerals potential of Wilderness study Areas in the Basin and Range Province, prepared for the Blireau of Land Management by the Great Basin GEM Joint Venture.

The principals of the Venture are Arthur Baker III, G. Martin Booth III, and Dennis P. Bryan. The study is principally a literature search supplemented by information provided by claim owners, other individuals with knowledge of some areas, and both specific and general experience of the authors. Brief field verification work was conducted on approximately 25 percent of the WSAs covered by the study.

None of the WSA in this GRA was field checked.

One original copy of background data specifically applicable to this GEM Resource Area Report has been provided to the BLM as the GRA File. In the GRA File are items such as letters frorn or notes on telephone conversations with claim owrers in the GRA or the WSA, piots of areas of Land Classification for Mineral Resources on maps at larger scale than those that accompany this report if such were made, original compilations of mining claim distribution, any copies of journal articles or other docliments that were acquired during the research, and other notes as are deemed applicable by the authors.

As a part of the contract that resulted in this report, a background document was also written: Geological Environments of Energy and Mineral Resources. A copy of this document is included with the GRA File to this GRA report. There are some geological environments that are known to be favorable for certain kinds of mineral deposits, while other environments are known to be much less favorable. In many instances conclusions as to the Favorability of areas for the accumulation of minerai resources, drawn in these GRA Reports, have been influenced by the geology of the areas, regardless of whether occurrences of valuable minerals are known to be present. This document is provided to give the reader some understanding of at least the most impcrtant aspects of geological environments that were in the minds of the authors when they wrote these reports. 


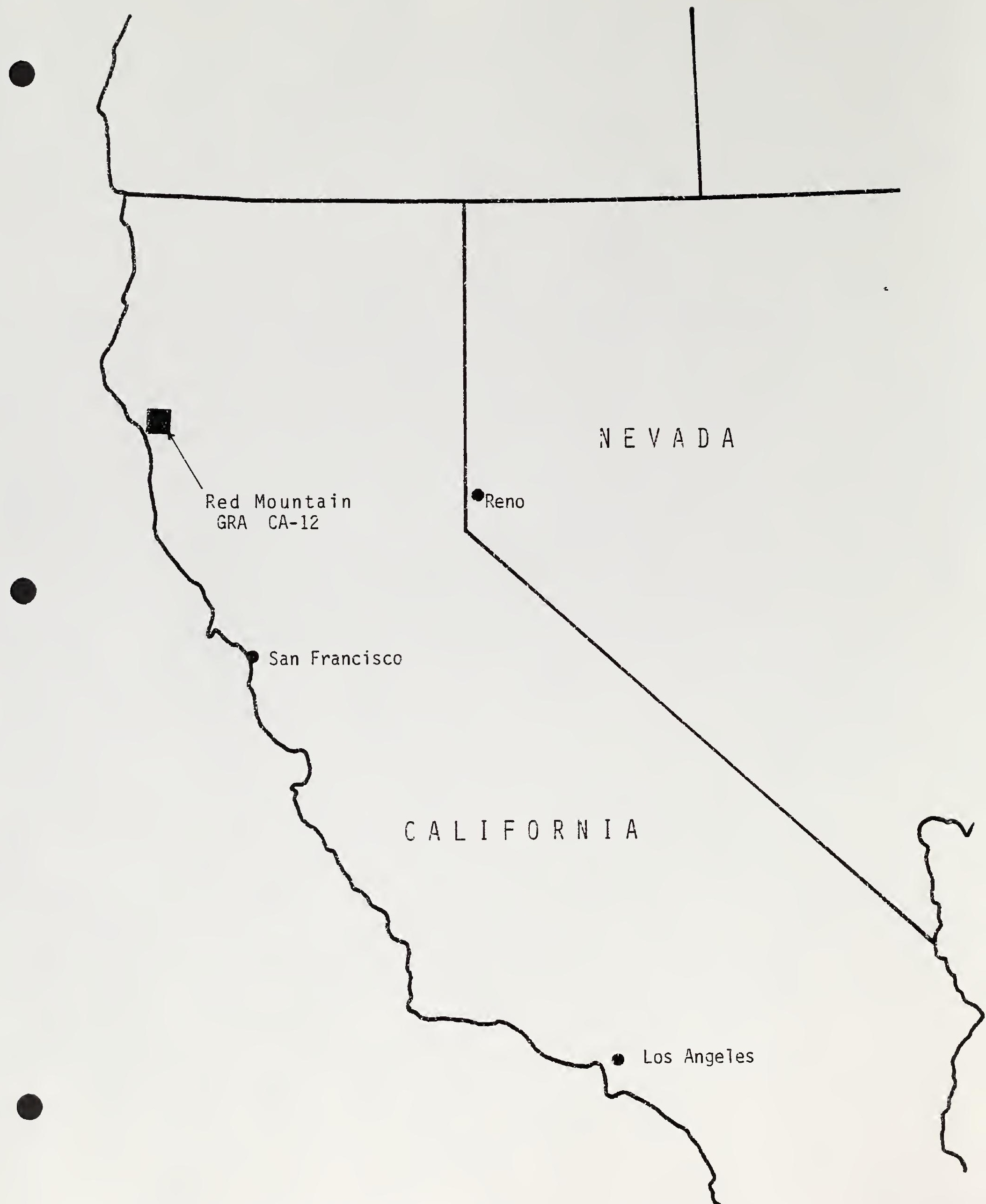

Figure 1. GRA index Map of Region $3 \quad 1: 5,000,000$ 


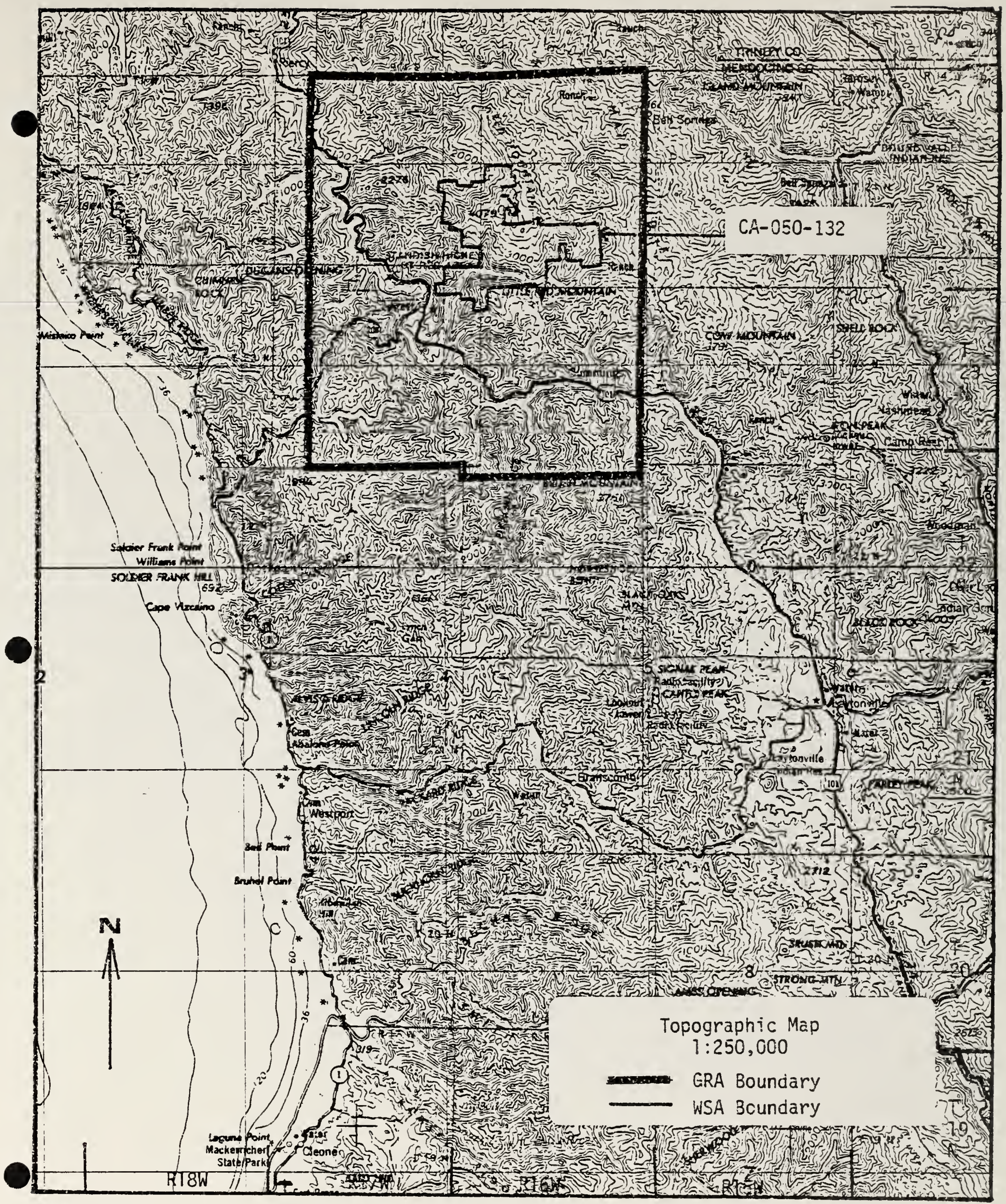

Ukian Sheet

Red Mountain GRA CA-12

Figure 2 


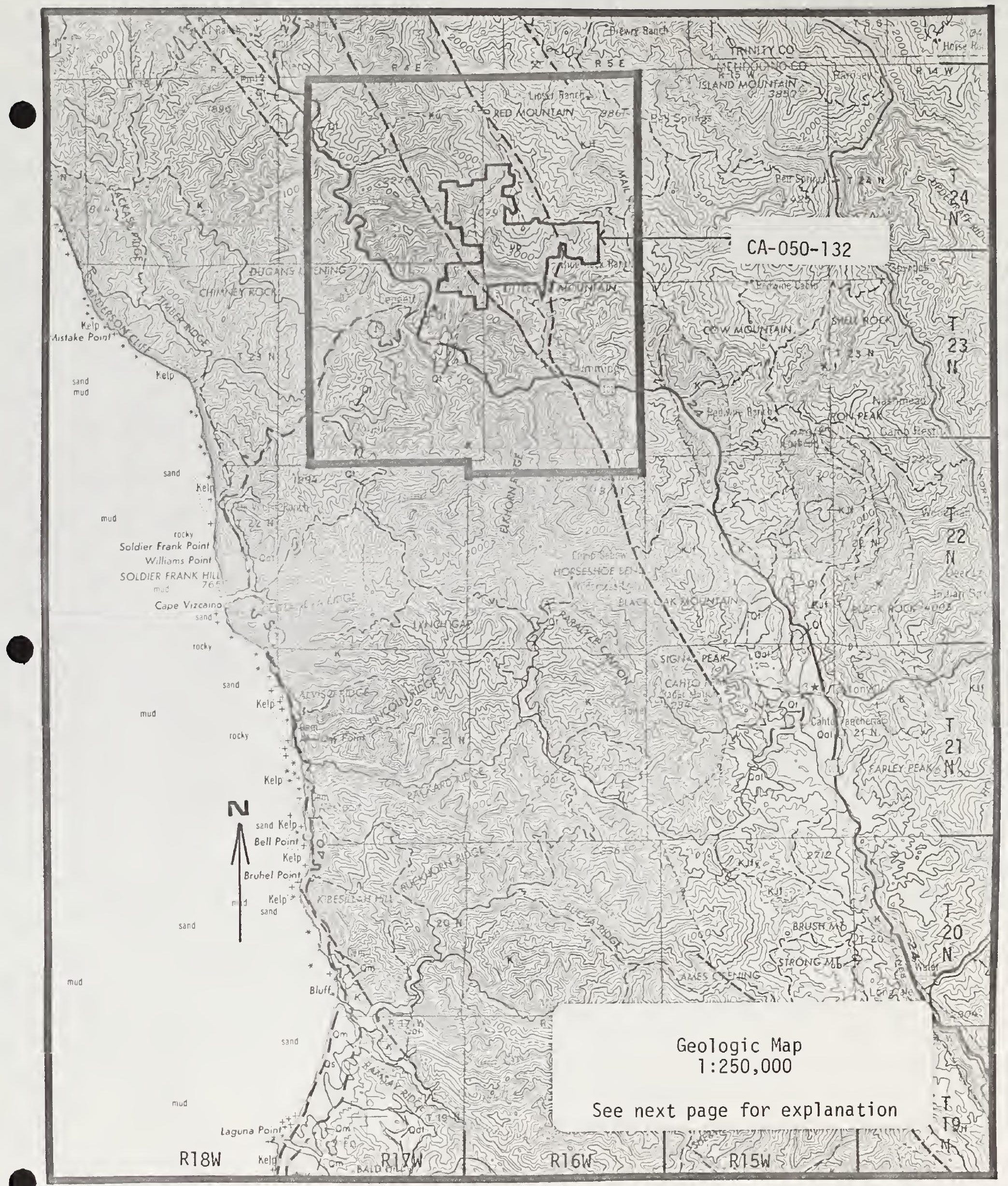

Ukiah Sheet, Jennings and Strand (1960)

Red Mountain GRA CA-12

Figure 3 


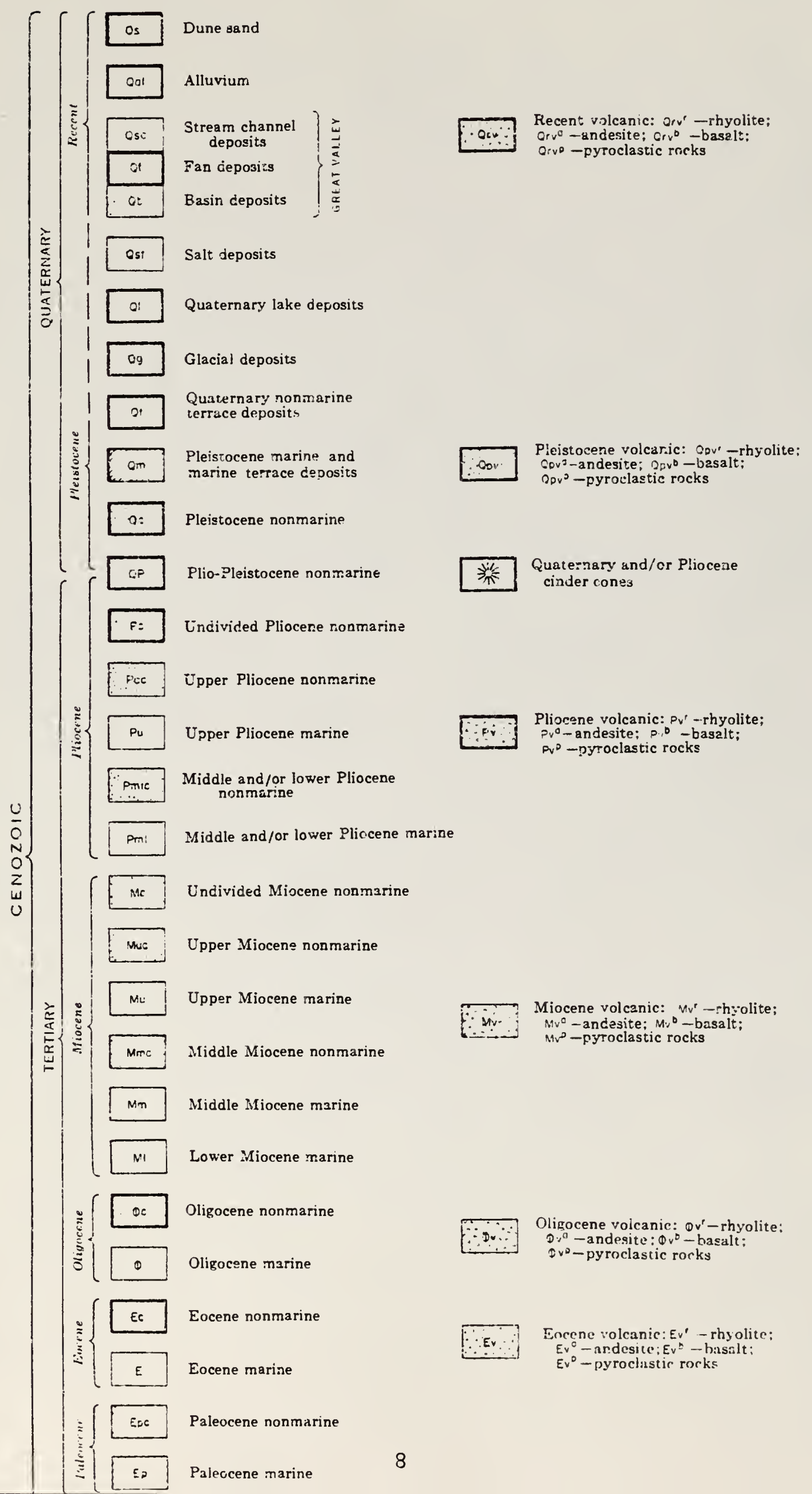



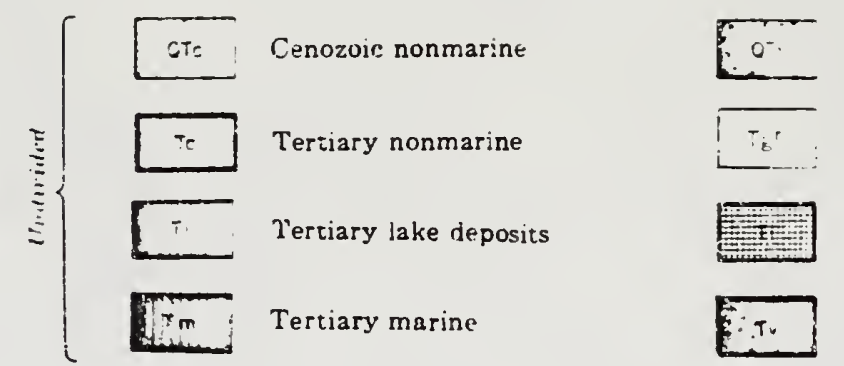

Cenozoic volcanic: $c^{\top} \cdot$-rinyolite: QTv ${ }^{0}$-andesite: oTv -basalt;

$a^{-}=-$pyroclastic recks

Fertiary granitic rouks

Tertary in rusive (hypabysai) rnckis: $T_{1}{ }^{\prime}$ - rhyolilc: $T_{1}{ }^{a}$-andesite: $T_{1} t$-basalt

Tertiary vol:anic: Tv' --rhyclite; to-andesite; TV -basalt:

- D -pyroclastic rocks

\section{k Undivided Cretaceous marine}

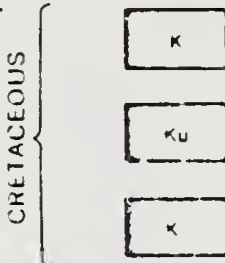

Upper Cretaceous marine

Lower Cretaceous marine

\section{uk}

F゙noxvill, Formation

Upper Jurassic marine

JinI

Middle and/or Lower
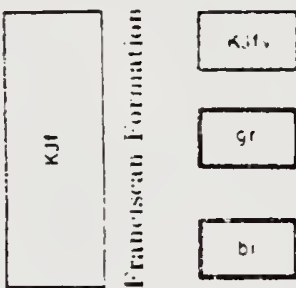

Franciscan volcanic and metavolcanic rocks

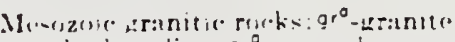

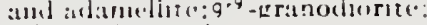
gr" tonatite and etrortte.

bi Mesozoic hasic intrusite rorks

ut

Mesuzoic u!trabastc intrusive rocks Jura-Trias metavolcanic rocks

\section{i. Triassic marine}

Pre-Cretaceous metanuophic rocke ( $1 \mathrm{~s}=$ limestone or dolomite

Pre-Cretaceous metavolcanic rocks

ms

Pre-Cretaceous metasedimeritary rocks

g.m Pre-Cenozoic granitic and metamorphic rocks

IP Paleozoic marine

( $s=$ imestone or dolonute

P. Paleozoic metavolcanic rocks

\section{耍}

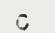

C

CP

CM

Mississippian marine

D

Devonian marine

5

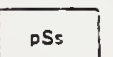

Siiurian marine

Pre-Silurian metasedimentary rocks

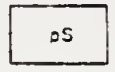

Ordovician marine

Cambrian marine

Cambrian - Piecambrian marine

Undivide'l Prerambr:ar

metamorphic rocks

oॄg $=$ gneiss, ots $=$ schist

Later Preatmbrian sedimentary and metamorphic roshs h. Permian metavolcanic rocks

Cv Carboniferous metavolcanic rocks

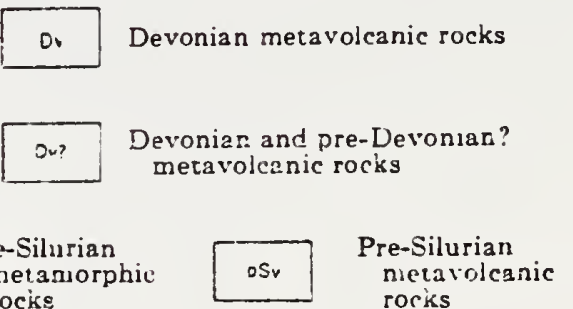

rocks

rorks 


\section{GEOLOGY}

We found no information on the general geology of the Red Mountain GRA nore detailed than that provided by the Jennings and Strand (1960) Uxian sheet of the Geologic Map of California. Other references are brief descriptions of specific manganese or chromite occurrences that shed no light on the complex structure or Iithology, and in most of them the locations of the occurrences are so unspecific that they have little meaning even as occurrence descriptions. This section on geology, then, is not as comprehensive as we could wish.

\section{PHYSIOGRAPHY}

The Red Mountain GRA is located within the Coast Range geomorphic province in northeri Mendocino County, California. The study area is due east of the town of Leggett which is between Piercy and Cummings on U. S. Highway I01.

The topography is dominated by high riages and narrow vallevs which trend northwest paraliel to the regional structure of the rocks. Elevations range from about 4,000 feet at Red Mountain to 1,000 feet in the lowest valleys.

Three northwest trending, east dipping belts of Mesozoic marine sediments occur in the stuay area. These formations are separated from one another by two northwest-trending faults which converge to the south bounding an ultramafic intrusive body.

\section{ROCK UNITS}

The GRA lies astride the junction of two northwest-trending faults that evidently have very large displacement. Jennings and Strand (1960) show four rock units here, all of them mosily Cretaceous.

East of the faults is a very extensive terrane underiain by the Junassic/Cretaceous Franciscan Formation, which Page (1966) describes as a disorderly assemblage of rocks. It includes deep-water sediments and mafic marine volcanic material, all locally accompanied by masses of serpentine, and all of which have undergone unsystamatic disturbance.

West of the faults are rocks shown by Jennings and strand (1960) as undivided Cretaceous marine rocks, but shown by fage (1966) as part of the Franciscan Formation. Between the faults is a northwest-trending strip of upper Cretaceous marine rocks about three miles wide. 
Also between the faults at their intersection is a body of ultramafic rocks three miles wide at most, and about six miles long (Jennings and Strand, 1960). Page considers that the ultramafic bodies intruded into the Fransciscan and related sedimentary rocks are probably segments of mantle rock torn loose by the intense tactonism the Franciscan has undergone. The ultrabasic body underlies muci of WSA CA 050-132, and the lateritic soil that results from the weathering of it is the locus of the nickel-cobalt-chromite mineralization that represents the known mineral potential of the WSA.

\section{STRUCTURAL GEOLOGY AND TECTONICS}

As has been mentioned, two major northwest-trending faults transect the GRA. No other faults are known in the GRA, and all other faults mapped (Jennings and Strand, 1950) in the region aiso trend northwest. Clearly there are a great many faults -- and so poorly exposed is this terrane that few workers have attempted to sort them cut anyuhere in the Franciscan. Page (1960) characterizes the situation thus: "Vieived in broad perspective, the entire Franciscan might be regarded as a gigantic tectonic zone at the fringe of the continent".

\section{PALEONTOLOGY}

Lithostratigraphic units within the Red Mountain GRA with paleontological potential include upper Cretaceous marine clastics ( $\mathrm{Ku}$ ), undivided marine Cretaceous (K) and undivided Franciscan Formation rocks (KjI) of Juro-Cretaceous age. Quaternary nonmarine terrace aeposits (Qt) have low potential for paleontological resources, although they may contain reworked fossils from underlying strata. Of tinose inits present within the GRA, the Upper Cretaceolis (Ku) has the highest probability of containing fossils, and several localities are known to occur within this unit but outside the GRA boundary; no localities are definitely known to be recorded Erom within the area. The lithology of the Wilaerness Study Area $050-132$ is mostly Mesczoic ultrabasic rocks (ub), which have no potential for paleontology.

\section{HISTORICAL GEOLOGY}

An extremely thick sequence of marine rocks, partly sedimentary and partly volcanic, were deposited in the Jurassic and Cretaceous to produce tine Franciscan Formation. some structural complexity may have been introduced by submarine sliding soon after the rocks were deposited, but a great deal of complexity resulted from extreme tectonic activity in the region that started perhaps not long afier deposition. In the Late Cretacecus marine sediments were deposited over the Franciscan. With continued tectonic 
activity slabs of mantle material were torn loose and intruded into the marine rocks to produce scattered bodies of ultramafic rocks.

Weathering of the liltramafic bodies, and specificaily the one that underlies WSA CA 050-132, produced nickel-ccbalt-chromium concentrations. 


\section{A. METALLIC MINERAL RESOURCES}

\section{Known Mineral Deposits}

According to Dow and Thayer (1946) the Guthrie property on Red Mountain shipped 100 tons of chromite cre from the largest of its deposits. This publication implies that additional ore was shipped from other deposits on the property. The location of the mine(s) is not specified.

Susan L. Skinner (1982), Geologist with the Ukiah District Office of BLM provided an outline of the overall distribution of lateritic soil derived from the ultrabasic body on the Noble Butte and Leggett 7 1/2-minute topographic quadrangles.

Steven D. Van Nort (1982), Exploration Geoiogist, Coastal Mining Company, provided parts of the same topographic maps, with an overlay showing "significant concentrations of nickel and cobalt" with the locations of 33 arill holes in and near the areas of concentrations that are witinin the boundary of WSA CA 050-132, and with a copy of an explanatory letter dated April 5, 1979 to Bruce Canr, of the Ukiah District office. These, tco, are in the GRA file.

According to James Brigint (1982), driling in the Red Mountain area during the mid-1950's delineated about 30 milion tons of laterite averaging $0.79 \%$ nickel. It is Mr. Bright's unaerstanding that further drilling by Coastal Mining Company in the late 1970's expanded tris to about 40 million tons of $0.8 \%$ nickel. he says that there is cobalt present, but the values are very low. He did not mention chromite.

Kirby and others (1982), in a largely-metallurgical report, present analyses of laterites from four localities, which show the nickel contents ranging from $0.74 \%$ to $1.12 \%, 0.06 \%$ to $0.1 \%$ cobalt and $1.29 \%$ to $1.44 \%$ chromium. The sample from "Red Flats", which is not otherwise identified but may be a misnomer for Red Mountain, contained $1.01 \%$ nickel, $0.06 \%$ cobalt and $1.42 \%$ ohromium.

2. Known Prospects, Mineral Occurrences and Mineralized Areas

There are no known metallic mineral prospects, occurrences of mineralized areas in the GRA other than the areas described above. 
There are no patented claims in the GRA. There is a band of sections about six miles long north-south and two miles wide east-west in which it appears that all public land has been covered by unpatented claims. This band of claims covers both of the areas indicated by Mr. Van Nort as having significant nickel and cobalt vaiues, as well as the red soil area between them. It covers the central part of WSA CA 050-132, probably more than half the total area of the WSA.

\section{Mineral Deposit Types}

The chromite deposits and the nicksl/cobalt deposits of the GRA were formed somewhat differently, althougin they occur essentially togetiner in the lateritic soil formed by weathering of the uItrabasic intrusive rock. The chromite occurs in small pods a few inches to a few seet thick and a Eew feet to ifity feet long (Dow and Thayer, 1946). These are magmatic segregations which were formed when the chromite crystailized out of the stili-liquid ultrabasic magma and settled to somewhere near the bottom of the magma chamber as a layer of more or less pure chroinite crystals. The poddy character presently displayed, probably results from the original fairly-continuous layer of chromite being torn into relatively small shreds -- the pods -- when the still semi-liquia, or perhaps solid mass of ultrabasic rock, was intruded intc its present position. Although the pods that are seen are in the laterite zone where the iltrabasic rock has been weathered, it is certain that their counterparts are to be found in unweathered ultrabasic rock at greater depth.

The nickel and cobalt also are part of the original ultrabasic rock, and may also have resided originally in minerals that crystallized out of the magma and settled, to enrich part of the magma in nickel and cobalt. Howsver, the nickel and cobalt minerais which were probably sulfice minerals, were not resistant to weathering. Instead, they disintegrated in the weathering process and some of their components were dissolved and washed away, but the nickel and cobalt remained in place, chemically rearranged into a new set of minerals. Probably the entire mass of ultrabasic rock originally had small quantities of nickel and cobalt minerals scattered more or less uniformiy through it, unlike the chromite, winich was concentrated in the pods in which it still occurs.

Both the chromite and the nickel/cobalt do have one feature in common. The lateritic soil in which they occur was formed by the weathering of the ultrabasic rock, which involved literally dissolving much of the rock and washing 
away the dissolved components. Since neither the chromite nor the nickel and cobalt were dissolved and washed away, the effect of this was to concentrate them in the material that remained -- the lateritic soil. This weathering and concentration took place some millions of years ago, at a time when the climate was probably subtropical and the land surface was essentialiy a flat plain rather than the present very steep, hilly terraire. The present lateritic soil, and the chromite and rickel/cobalt deposits, are the remnants of that period of weathering. Most of the laterite and the valuable minerals were eroded away as the present surface was being formed.

\section{Mineral Economics}

"U.S. nickel reserves total about 360,000 tons in lateritic material containing $0.8 \%$ to $1.3 \%$ nickei. All are in deposits at the operating mine near Riddle, oregon Other nickeliferous lateritic deposits are in oregon, California and Wasinington; and some parts of tinese deposits are as high grade as the reserves at Ricile, but they are not mineable at a profit under current economic conditions." (Matthews and Sibley, 1980).

The Red Mountain nickel deposits are undoubtedly inciuded in those mentioned by Matthews and sibley as not being mineable at a profit under current conditions. The mine at Ridale closed cown in 1982 after some 20 years of operation, apparentiy having become ureconomic because of the combined effects of a worla-wide glut of nickel and the increasing cost of electricity needed for its processing.

The grade of the nickel deposit at Red Mountain is about the same as the lower grade ore reserves at Ridaie; it is submarginal, but not greatly so. The current glut of nickel is likely to continue for some years, since there are several large deposits that have been developed or partly developed in the past ten years. However, the glut will eventialiy end, and in ali likelihood the Red Mountain deposit will then become economic. It is ore of the few potentialiy economic deposits of nickel known in the United States.

More than 90 percent of nickel used is in the form of metal, mostly in alloys where it imparts corrosion resistance, strength, and other desired characteristics. The remaining uses include batteries, dyes, insecticides and as a catalyst. For the past twenty years united States production of nickel ranged between 10 thousand and 20 thousand tons, but in 1982 the single nickel mine in the country, at Riddle, oregon, ceased operation and presently there is no domestic production except for small quantities as byproducts of smelting. United States 
demand is close to 200 thousand tons per year, most of which is imported from Canada. Nickel is listed as a strategic and critical metal. United States demand is forecast to about double by the year 2000, but the best forecast for production falls far short of that quantity, and the most pessimistic estimates foresee no domestic nickel production. The price of nickel at the end of 1982 was $\$ 3.29$ per pound.

Cobalt is used mostly in heat- and wear-resistant materials such as alloys for jet engine parts and the metal matrix of tungsten carbide cutting tools. Substantial amounts are used in permarent magnets, and as aryers or pigments in paints, with lesser uses in glassmaking and ceramics. The United States uses about 20 miliion pounds per year and produces none. The principal suppliers are Ziare (more than half of U. S. imports) and Zambia, with lesser amounts from several other countries. Cobait consumption in the United States is forecast to increase by about fifty percent by the year 2000; domestic production is forecast to be zero in 2000, but possible production is estimated at 20 to 30 percent of demand. The price of cobalt is about $\$ 25$ per pound.

Chromium is one of modern industry's essential and versatile elements. About 60 percent of it is used in a very wide range of metallurgicai alloys, especially stainless steel, and 10 percent is used in retractory linings for furnaces and kilns. Ten percent is used in chemicals, and another 10 percent in miscellanoues applications. The familiar chrome plate, as on automobile bumpers, actually accounts for an almost-infinitesimal part of total use. United states consumption of chromium is about one-half million short tons per year, ali of which is imported and nearly all from the Eastern Hemisphere. Chromium is listed as a strategic and critical metal. United States consumption is foresast to about double by the year 2000, and domestic production is forecast to remain at zero. The price of chromite, the mine-proauct mineral from which chromium is extracted, is somewhat over $\$ 100$ per ton, but can vary quite widely as a result of political actions in the producing nations.

B. NONMETALLIC MINERAL RESOURCES

1. Known Mineral Deposits

No nonmetallic mineral deposits are known in WSA Ca 050132. Some chromite is used as a refractory in furnace linings and similar high-temperature applications. In that usage it is essentialiy a nonmetaliic mineral, as opposed to being a metallic mineral when used in the chemical industry, or in the metaliurgical industry for making alloys. The use that was made of chromite produced 
from Red Mountain is not known, so it is considered in this report as having been usea for metallurgical applications and thus as a metalic mineral.

2. Known Prospects, Mineral Occurrences and Mineralized Areas No nonmetallic prospects, mineral occurrences or mineralized areas are known in WSA CA 050-132.

3. Mining Claims, Leases and Material Sites

No mining claims located for nonmetaliic minerals can be distinguished in WSA CA 050-132.

No nonmetallic mineral leases ard no material sites are known in WSA CA 050-132.

4. Mineral Deposit Types

There are no nonmetallic mineral deposits to be described.

5. Mineral Economics

There are no nonmetallic minerals, the economics of which to consider.

\section{ENERGY RESOURCES}

Uranium and mhorium Resources

1. Known Mineral Deposits

There are no known uranium or thorium aeposits in the WSA. or GRA.

2. Known Prospects, Mineral Occurrences and Mineralized Areas

There are no known uranium or thorium occurrences in the IVSA or GRA. The only known radioactive occurrences in the area are two uranium and four thorium aerial radiometric ancmalies which occur over Jurassic-cretaceous marine seaimerts (Western Geophysical Company of America, 1981) to the east of the GRA. These occurrences are indicated on the Uranium Land Classification and Mineral Occurrence Map, inciuded in this report. 
3. Mining Claims

There are no known uranium or thorium claims or leases in the WSA or GRA.

4. Mineral Deposit Types

Uranium and thorium deposit types cannot be discussed due to the lack of such deposits in the IVSA or GRA.

5. Mineral Economics

Uranium and thorium are probably of no economic value in the WSA or GRA due to the lack of occurrences of these elements.

\section{Oil anä Gas Resources}

There are no oil and gas fields, hydrocarbon shows in wells, or surface seeps in the region, and the Mesczoic Franciscan Formation of deep-water sediments and marine volcanic material is not a promising source/reservoir rock sequence. There are no Federal oil and gas leases in the GRA, but there are four sections under lease just outside the GRA (see Oil and Gas Lease Map). There is no oil and gas occurrence and land classification map in this report.

Geothermal Resources.

I. Known Geothermal Deposits

There are no geothermal deposits present in the GRA.

2. Known Prospects, Geothermal occurrences and Geothermal Areas

There are no known geothermal occurrences within tine GFA. Eight miles to the southeast Jackson Valley Mud springs $\left(27^{\circ} \mathrm{C}\right.$ at $\left.1 \mathrm{I} / \mathrm{min}\right)$ and pinches Spring $\left(21^{\circ} \mathrm{C}\right.$ at $\left.190^{\circ} \mathrm{l} / \mathrm{min}.\right)$ represent the closest known thermal waters (Geothermal Occurrence and Land Classification Map).

3. Geothermal Leases

There are no geothermal leases or lease applications in the region, and no geothermal lease map is included in this report. 
4. Geothermal Deposit Types

There are no geothermal resources of record within the Red Mountain GRA.

\section{Geothermal Economics}

There are no geothermal resources of record within the Red Mountain GRA.

Geotinermal resources are utilized in the form of hot water or steam normally captured by means of drilling wells to a depth of a few feet to over 10,000 feet in depth. The fluid temperature, sustained flow rate and water chemistry characteristics of a geothermal reservoir determine the depth to which it will be economicaliy feasible to drill and develop each site.

Higher temperature resources (above $350^{\circ} \mathrm{F}$ ) are currently being lised to generate electicical power in Utah and California, and in a number of foreign countries. As fuei costs rise and technology improves, the iower temperature limit for power will decrease appreciably -- especially for remote sites.

All thermal waters can be beneficially used in some way, including fish farming $\left(68^{\circ} \mathrm{F}\right)$, warm water for year around mining in cold climates $\left(86^{\circ} \mathrm{F}\right)$, residential space heating $\left(122^{\circ} \mathrm{F}\right)$, greenhouses by space heating $\left(176^{\circ} \mathrm{F}\right)$, drying of vegetables $\left(212^{\circ} \mathrm{F}\right)$, extraction of salts by evaporation and crystallization $\left(266^{\circ} \mathrm{F}\right)$, and drying of diatomaceous earth $\left(338^{\circ} \mathrm{F}\right)$.

Unlike most mineral commodities remoteness of resource location is not a drawback. Dcmestic and commercial use of natural thermal sprincjs and shaliow wells in the Basin and Range province is a historical Eact for over 100 years.

Development and maintenance of a resource for beneficial use may mean no dollars or hundreds of millions of dollars, depending on the resource characteristics, the end use and the intensity or level of use.

\section{OTHER GEOLOGICAL RESOURCES}

No other geological resources are known in WSA CA 050-132. 
A list of strategic and critical minerals and metals provided by the BLM was used as a guidelire for the discussion of strategic and critical materials in this report.

The Stockpile Report to the Congress, October 1981-March 1982, states that the term "strategic and critical materials" refers to materials that would be needed to supply the industrial, military and essential civilian needs of the United states during a national emergercy and are not found or produced in the United States in sufficient quantities to meet such need. The report does not define a distinction between strategic and critical minerals.

Nickel, cobalt and chromium are all strategic and critical metals. The United States is dependent lipon imports for virtualiy ali its needs from all three metals, and there are very few deposits of any of them in the United States that are potentially mineable even under circumstances in which profitability is not an important factor. 
The quaity of published geological mapping in the GRA is abysmally low: it is at a scale of $1: 250,000$ with only very gross structures shown. This is excusable in view of the combination of extremely complex structure and poor exposures. Information concerning chromite occurrences is very poor, principaliy because locations are indefinite. Information abcut the ultrabasic body in which the nickei-cobalt-chromite bodies occur, and about the bodies themselves, is very gocd, thanks to the maps provided by Skinner (1982) and Van Nort (1982). Information about tonnages and grades, though general and unsupported by hard data, is good. overall, the data on mineral resources is good, better than in most GRAs, except for the lack of verifiable backup.

Land classification areas are numbered starting with the number I in each category of resources. Metallic mineral land classification areas have the prefix M, e.g., MI-4D. Uranium and thorium areas have the prefix U. Nonmetallic mineral areas have the prefix N. Oil and gas azeas have the prefix OG. Geothermal areas have the prefix G. Sodium and potassium areas have the prefix S. The saleable resources are classified linder the nonmetallic mineral resource section. Both the classification Scheme, numbers 1 througin 4 , and the Level of Confidence Scheme, letters $A, B, C$ and $D$, as supplied by the BLM are included as attachments to this report. These schemes were used as strict guicieines in developing the mineral classification areas used in this report.

Land classifications have been made here only for the areas that encompass segments of the WSi. Where data outside a WSA has been used in establishing a classification area witrin a WSA, then at least a part of the surrounding area may also be included for clarification. The classified areas are shown on the 1:250,000 mylars or the prints of those that accompany each copy of this report.

In connection with nonmetaliic mineral classification, it should be noted that in all instances areas mapped as alluvium are ciassified as having moderate favorability for sand and gravel, with moderate confidence, since alluvium is by definition sand and gravei. All areas mapped as principally limestone or dolomite have a similar classification since these rocks are usable for cement or lime production. All areas mapped as other rock, if they do not have specific reason for a different classification, are classified as having low favorability, with low confidence, for nonmetallic mineral potential, since any mineral material can at least be used in construction applications. 


\section{LOCATABLE RESOURCES}

a. Metaliic Minerals

WSA CA $050-132$

MI-4D, M2-4D, M3-4D. These three areas are ali geologically the same -- they are areas of nickeliferous laterite. The outlines on the Metaliic Mineral Occurrence and Land Classification Map are taken from the $1^{\prime \prime}=2,000^{\prime}$ map provided by Mr. Van Nort of Coastal Mining which is in the GRA file. Rather small edge areas of each classification area extend into WSA CA 050-132. In these areas there have been at least three separate, extensive exploration programs by industry: in the early $1950 \mathrm{~s}$ by Freeport Mining Company(?), in the mia-1950s by union Carbide Corporation (Bright, 1982), and in the late 1970s until about the present by Coastal Mining Company There has also been at least one sampling program by the U. $S$. Bureau of Mines, in the late l970s (Rice, 1982). According to Mr. Bright (1982) the industry programs at least indicated, if they did not prove, 30 or 40 miliion tons of material with about $0.8 \%$ nickel. The tonnages and grade are probably sufficient to support a mire under the proper economic conditions, although the material could by no means be mined under the present economic conditions. It is worth noting also that nickel is a stragegic and critical mineral, and the deposits might be mined regaraless of the economics in some world-wide political situations. This is the reasoning behind the classification of 4 .

The tonnage and grade figure:s are hearsay, without documentary backup, but the fact that three companies explored the area in sequence tends to support them at least generally. Coastal may not have had available to it all the information from the earlier projects, but at the very least it picked up through the mining industry rumor mill the knowledge that those projects indicated substantial tonnage of material with high enough grade that it might be worth mining. Otherwise, Coastal would not have tackled the project. On this line of reasoning, the quoted tonnage and grade seem reasonable. This is the reasoning behind the $D$ level of confidence.

M4-3B. This area encompasses all of the area of the "lateritic soil" as outined on the map in the GRA file provided by Ms. Skinner (1982), except those parts included in $M 1, M 2$ and $M 3$. It covers the middie of WSA CA 050-132. It is the area in which red soil indicates that the ultrabasic body lies beneath the surface. The red soil is not necessarily laterite, however. The laterite was produced by slow weathering of the ultrabasic rock over a very long period of time, during which many components of the rock were leached away but the nickel, 
cobalt and chromite remained behind and became enriched because the other materials were removed. Such weathering happened at Red Mountain only during a period some militions of years ago. Modern weathering of the ultrabasic rock produces the same red-colored soil, but it is rapid?y washed away on the steep present-day slopes, so there is no chance for the nickel, cobalt and chromite to accumulate and make a relatively metalic-enriched soil. The lateritic soil areas of $M_{1} I, M 2$ and $M 3$ lie on relatively broad flat mesas that have the highest elevations in their vicinity. The broad flat tops are the remnants of the plain on which the laterites were developed. Between these areas elevations are lower and slopes are steeper. The lateritic soils, if they were developed here, have been eroded away by modern erosion.

With this interpretation, the lower, steeper slopes cannot have laterite, and therefore probably can not have potentially economic nickel deposits. However, Bright (1982) points out that the letexite area of Little Red Mountain, classification area M3, is appreciably lower than the laterite areas on Red Mountain. He considers that there is a post-laterite fault between the two mountains, and that the south siae of this has been dropped relative to the north side. This is a reasonable way to account for the difference in elevation. However, if there is one fault, it is cossible there are other faults -- perhaps many fauits -- and these faults may have dropped other segments of the laterite zone to lower elevations. Apparently no additional segments of laterite zone have been found, but it is possible that they are present but hidden under scree and other debris from the slopes above. This is the reasoning behind the classification of 3 and the confidence level of $B$.

M5-1A. This is the area surrounding the classification areas described above -- the area of Franciscan and other Cretaceous sediments surrounding the body of ultrabasic rocks. It covers the eastern and western parts of WSA CA 050-132. There is no potential for nickel-cobalt-chromite mineralization such as occurs in the ultrabasic rock. These seaimentary rocks are not known to have potential for any mineralization in this area, although elsewhere manganese deposits are known to occur in them. This is the reason for the classification of 1 , and the level of confidence of $A$. There is no reason to anticipate mineralization here, but there is no evidence that there is none. 
b. Uranium and Thorium

WSA CA $050-132$

Ul-1A. This land classification covers all of the WSA and GRA. The area is covered by Mesozoic sediments which were derived largely from mafic volcanic rocks and ultrabasic intrusive rocks. The secimentary rocks are possible host rocks for uranium deposits, but the mafic to ultramafic igneous rocks exposed in the area are very poor sources of uranium. For this reason the area has no known favorability for uranium deposits at a very low level of confidence.

The lack of granitic or pegmatitic source rocks in the vicinity makes the area unfavorable for thoriun deposits.

c. Nonmetallic Minerals

WSA CA $050-132$

N1-2B. This land classification area covers ail of the WSA and the GRA. No nonmetallic mineral occurrences are known in the GRA. However, any mineral material can become an economically mineable commodity if someone can capitalize on its particular characteristics to develop a market for it. This is the reason for the low favorability classification and the low level of confidence in the classification.

\section{LEASABLE RESOURCES}

a. Oil and Gas

WSA CA C5D-132

OGI-ID. There has been no recorded oil and gas drilling in the WSA, GRA or vicinity. This sector of the Coast Ranges is underlain by the highly distorted Franciscan Formation not known to be a promising section for the generation or accumulation of hydrocarbons.

b. Geotherma 1

WSA CA $050-132$

Gl-2A. This classification encompasses the entire GRA. The general region immediately to the south has many geothermal occurrences, and there is some structural continuity extending northward into the WSA. 
c. Sodium and Potassium

SI-ID. The entire GRA has no known potential for either sodium or potassium resources, and is classified ID for these comnodities. No map for sodium and potassium is presented.

3. SA.LEABLE RESOURCES

Saleable resources are included in the section on Nonmetallic Minerals, above. 


\section{RECOMMENDATIONS FOR ADDITIONAL WORK}

1. Any field work that might be done by or for the BLM is almost certain to be a duplication of work similar to that which has already been done by at least a couple of mining companies, and perhaps severaI. Therefore, no field work is recommended.

2. The report made by the U. S. Bureau of Mines on its 1979 work is confidential, but perhaps can be acquired by the BLM as a fellow Federal agency. Its confidentiality probably wouid have to be preserved, but perhaps it could be released to the public with the approval of Coastal Mining Company. According to Mr. Rice the work was confined to the known laterite areas, which are already known to have high nickel concentrations, so it may have little to add other than confirmation (or negation) of the points concerning them made in the present report. It will not add any information that might modify the classification of area M4, about which very little is really known.

3. An effort should be made to get detailed information from the companies that have worked in the area. Freeport and union Carbide presumably are no longer interested in the area, and might be free with their information. Coastal Mining may be more difficult. The objective should be to get data on the area of M4; data that might indicate where there could be unoiscovered fault segments of nickelifercus laterite, or alternatively, might indicate that there are no such segments. 
Anderson, 1938, Lower Cretaceous deposits in California and Oregon: Geol. Soc. America Special Paper 16.

Anderson, F. M., 1902, Cretaceous Deposits of the Pacific Coast: California Acad., Sci., Proc (3), v. 2.

Anderson, F. M., 1932, Jurassic and Cretaceous divisions in the Knoxville-Shasta succession of California: Calif. State Div. Mines, Rept. 28 .

Anderson, F. M., 1958, Upper Cretaceous of the Pacific Coast: Geol. Soc. America Memoir 71.

Bailey, E. H., and Irwin, W. P., 1959, K-feldspar content of Jurassic and Cretaceous graywackes of the northern Coast Ranges and Sacramento Valley, California: Am. Assoc. Petroleum Geologists Bull., v. 43, no. 12 .

Becker, G. F., 1885, Notes on the stratigraphy of California: United States Geol. Survey, Bull. i9.

Bradley, W. W., and other, 1918, Manganese and chromium in California: California Min. Bur. Bull. 76. Brief description of Red Mountain chronite occurrences.

Bright, J. H., 1982, Oral communication to Arthur Baker III November 29, 1982: notes in GRA file. Size and grade of nickel resource.

California Division of Oil and Gas, 1964, Exploratory wells drilled outside of oil and gas fields in California to December 31, 1963: State of California, the Resources Agency, Dept. of Conservation.

Clark, S. G., 1940, Geology of the Covelo district, Mendocino County, California: California Univ., Dept. Geol. Sci. Bull. v. 25, no. 2 .

Diller, J. S., 1891, Notes on the Cretaceous rocks of northern California: American Jour. Science., (3) Vo. 40.

Dow, D. H., and Thayer, T.P., 1946, Chromite deposits of the northern Coast Ranges of California: California Div. Mines Bull. 134, pt. 2, ch. 1.

Fairbanks, H. W., 1892, The pre-Cretaceous age of the metamorphic rocks of the California Coast Ranges: Am. Geol., vol. 9.

Fairbanks, H. W., 1896, The age of the California coast ranges: Am. Geol., vol. 18 . 
Garside, L. J. and Schilling, J. H., 1979, Thermal waters of Nevada: Nevada Bureau of Mines and Geology, Bull. 91.

Goodyear, W. A., 1980, Mendocino County: California Min. Bur. Rept. 10, pp. 114-322.

Irelan, W. Jr., 1888, Mendocino County: California Min. Bur. Rept. 8 .

Irwin, W. P., 1957, Eranciscan Group in Coast Ranges ana its equivalents in Sacramento Valiey, California: Am. Assoc. Petroleum Geologists BuIl., v. 4I, no. 10 .

Jenkins, O. P., 1943, Geomorphic provinces: California Div. Mines Buli. Ils.

Jennings, C. W., and Strand, R. G., 1960, Geological map of California, Ukiah sheet, California Division of inines and Geology.

Kirby, D. E., George, D. R., and Daellenbach, C. B., 1982, Chromium recovery from nickel-cobalt laterite and laterite leach residue: U. S. Bur. Mines Report of Investigations 8676 . Onesample analyses of nickeliferous laterites from several localities but the localities are not clearly identified. Fhotocopy of page with analyses is in GRA file.

Lawson, A. C., 1894, The geomorphogeny of the coast of northern California: California Univ., Dept. Geol. Sci. Bull., v. I, no. 8. Lowell, F. L., 1914, Mendocino County: California Min. Bur. Rept. 14.

Matthews, N. A., and Sibley, S.F., 1980, Nickei, in Mineral Facts and Problems, 1980 edition: U. S. Bur. Mines Buli. 671.

MIIS, 1982, U. S. Bureau of Mines computer daia base. No mineral localities entered in the Red Mountain GRA.

Muffler, L. J. P., ed., 1979, Assessment of geothermal resources of the United States - 1978: U. S. Geol. Survey Circ. 790.

NOAA/National Oceanic and Atmospheric Administration, 1980, Geothermal resources of California: Map prep. by Nat. Geophy. and Solar-Terrestrial Data Center from data compiled by California Division of Mines and Geology, California Geologic Data Map Series, Map No. 4.

O'Brien, J. C., 1953, Mines and mineral resources of Mendocino County, California: California Jour. Mines and Geology, v. 49, no. 4 .

Packard, E. L., 1916, Mesozoic and Cenozoic Mactrinae of the Pacific Coast of North Anerica: Univ. Calif. Publ., BuIl. Dept. Geol., vol. 9. 
Page, B. M., 1966, Geology or coast ranges of California, overview in Bailey, E. H., editor, Geology of northern California:

California Division of Mines and Geology Bull. 190.

Reed, R. D., I933, Geology of California: American Assoc. Petrol. Geologists, vol. 24 .

Reeside, J. B., Jr., 1927, The Scaphites, an Upper Cretaceous ammonite group: U. S. Geol. Survey Prof. Paper 150B.

Rice, W. L., 1982, Oral communication to Arthur Baker III December 2, 1982: notes in GRA file. Generalities about USBM 1979 sampling program. Distribution of laterite.

Skinner, S., 1982, Noble Butte and Leggett 7 1/2 minute topograpinic quadrangles with outline of red lateritic soil on Red Nountain and Little Red Mountain, and outline of WSA CA 050-132. In GRA file.

Stanton, T. W., 1895, Contributions to the Cretaceous paleontology of the Pacific Coast; the fauna of the Knoxville beds: U. S. Geol. Survey Bull. 133 .

Stanton, T. W., 1896, The faunal relations of the Eocene and Upper Cretaceous on the Pacific Coast, U. S. Geol, Survey, 17th Ann. Report, Pt. 1 .

Taliaferro, N. L., and Hudson, F. S., 1943, Genesis of the manganese deposits of the Coast Ranges of California: California Div. Mines Buli. 125. Concerns Franciscan Formation.

Trask, P. D., and others, 1950, Geologic descriptions of the manganese deposits of California: California Div. Mines Bull. 152.

irask, P. D., 1950, Geologic description of the manganese deposits of California: California Div. Mines BuII. 152 (Suppl. to Bul1. 125 ).

Trask, P. D., Wilson, I.F., and Simons, F. S., 1943, Manganese deposits of California, a sumnary report in Manganese in California: California Div. Mines Bull. 125.

Trexler, D. T., Koenig, B. A., and Flynn, T., compil., I980, Geothermal resources of Nevada and their potential for direct utilization: Nevada Bur. Of Mines and Geol., Map prepared for the U. S. Dept. of Energy under contract ET-78-S-08-1556.

Van Nort, S. D., 1982, Letter to Arthur Baker III, dated November 15, 1982, as cover letter to earlier letter of April 15, 1979 to Bruce Cann and $I^{\prime \prime}$ to 2,000' overlay on topographic quadrangles, showing outlines of nickeliferous laterites on Red Mountain and Little Red Mountain. In GRA sile. 
Weaver, C. E., 1949, Geology of the Coast Ranges immediately north of the San Francisco Bay Region, California: Geol. Soc. America Memoir 35.

Western Geophysical Company of America, Aero Service Division, 1981, Airborne gamma ray spectrometer and magnetometer survey, Ukiah Quadrangle, California: U. S. DOE, Open File Report GJBX $390(81), 199$ p. 


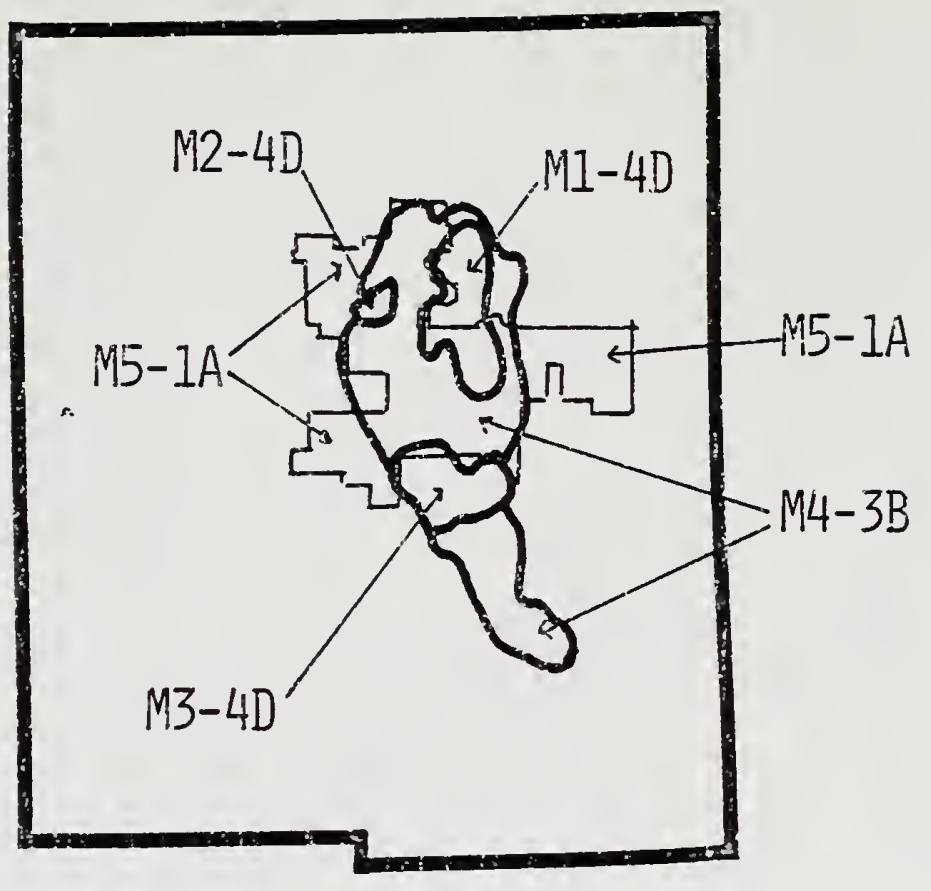

EXPLANATION

- WSA Boundāry

- Land Classification Boundary

Land Classification - Mineral Occurrence Map/Metallics

Red Mountain GRA CA-12

Scale 1:250,000 


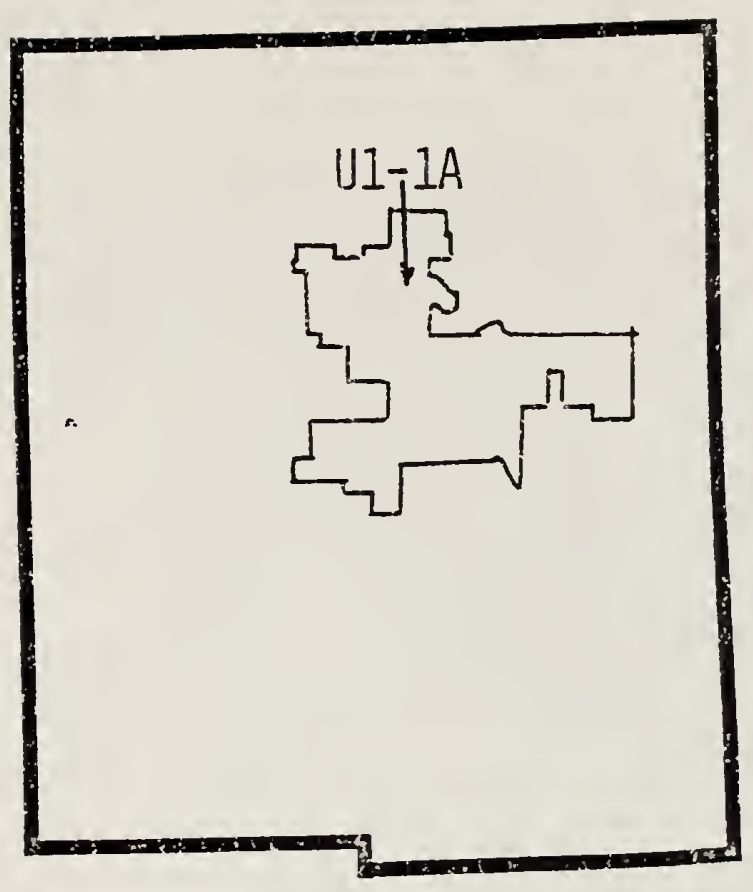

-

\section{-}

\section{EXPLANATION}

- Uranium Dccurrence

- WSA and Land Classification Boundary 


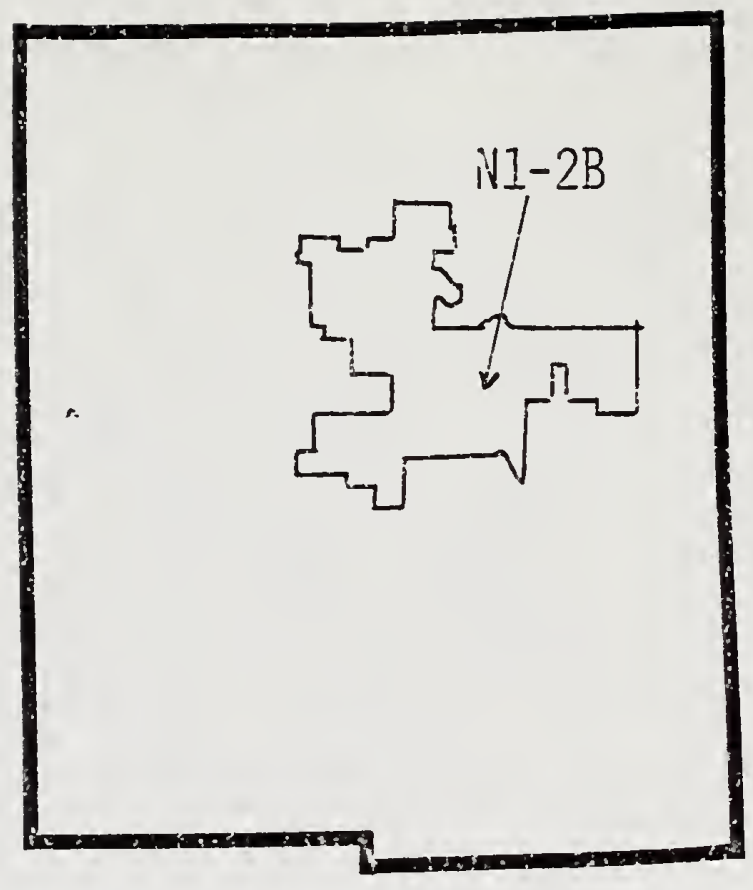

\section{EXPLANATION}

- WSA and Land Classification Boundary 


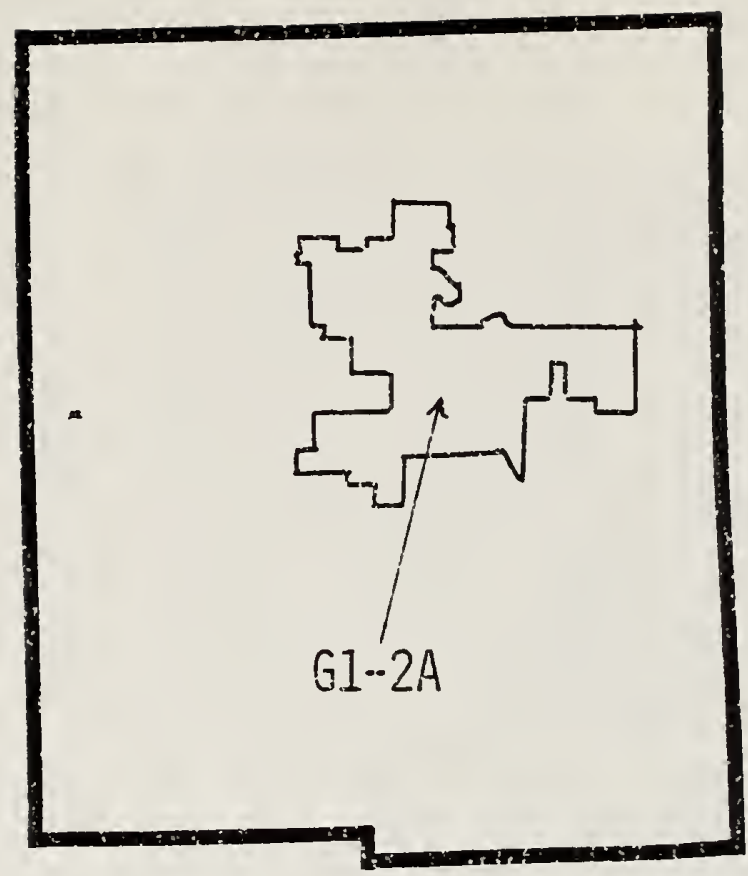

Q

$\rho$

\section{EXPLANATION}

Thermal spring

WSA and Land Classification Boundary

Land Classification - Mineral Occurrence Map/Geothermal

Red Mountain GRA CA-12 


\section{LEVEL OF CONFIDENCE SCHEME}

A. THE AVAILABLE DATA ARE EITHER INSUFFICIENT AND/OR CANNOT BE CONSIDERED AS DIRECT EVIDENCE TO SUPPORT OR REFUTE THE POSSIBLE EXISTENCE OF MINERAL RESOURCES WITHIN THE RESPECTIVE AREA.

B. THE AVAILABLE DATA PROVIDE INDIRECT EVIDENCE TO SUPPORT OR REFUTE THE POSSIBLE EXISTENCE OF MINERAL RESOURCES.

c. The AVAILABLE DATA PROVIDE DIRECT EVIDENCE, BUt ARE QUANTITATIVELY MINIMAL TO SUPPORT TO REFUTE THE POSSIBLE EXISTENCE OF MINERAL RESOURCES.

D. THE AVAILABLE DATA PROVIDE ABUNDANT DIRECT AND INDIRECT EVIDENCE TO SUPPORT OR REFUTE THE POSSIBLE EXISTENCE OF MINERAL RESOURCES. 


\section{CLASSIFICATION SCHEME}

1. THE GEOLOGIC EIVI RONMENT AND THE INFERRED GEOLOGIC PROCESSES DO NOT INDICATE FAVORABILITY FOR ACCUMULATION OF MINERAL RESOURCES.

2. THE GEOLOGIC ENVIRONMENT AND THE INFERRED GEOLOGIC PROCESSES INDICATE LOW FAVORABILITY FOR ACCUMULATION OF MINERAL RESOURCES.

3. THE GEOLOGIC ENVIRONMENT, THE INFERRED GEOLOGIC PROCESSES, AND THE REPORTED MINERAL OCCURRENCES INDICATE MODERATE FAVORABILITY FOR ACCUMULATION OF MINERAL RESOURCES.

4. THE GEOLOGIC ENVIRONMENT, THE INFERRED GEOLOGIC PROCESSES, THE REPORTED MINERAL OCCURRENCES, AND THE KNOWN MINES OR DEPOSITS INDICATE HIGH FAVORABILITY FOR ACCUMULATION OF MINERAL RESOURCES. 
MAJOR STRATIGRAPHIC AND TIME DIVISIONS IN USE BY THE U.S. GEOLOGICAL SURVEY

\begin{tabular}{|c|c|c|c|c|}
\hline $\begin{array}{c}\text { Erathem or } \\
\text { Era }\end{array}$ & & System or Period & Series or Epoch & $\begin{array}{l}\text { Estimated ares of } \\
\text { time boundaries in } \\
\text { millions of years }\end{array}$ \\
\hline \multirow{7}{*}{ Cenozoic } & \multirow{2}{*}{\multicolumn{2}{|c|}{ Quaternary }} & Holocene & \multirow[b]{2}{*}{$2-3^{3}$} \\
\hline & & & Pleistocene & \\
\hline & \multirow{5}{*}{\multicolumn{2}{|c|}{ Tertiary }} & Pliocene & $-12^{2}$ \\
\hline & & & Miocene & $26^{\prime}$ \\
\hline & & & Oligocene & $37-38$ \\
\hline & & & Eocene & -53.54 \\
\hline & & & Paleocene & \\
\hline \multirow{3}{*}{ Mesozoic } & & Cretaceous & $\begin{array}{l}\text { Upper (Late) } \\
\text { Lower (Early) }\end{array}$ & -136 \\
\hline & \multicolumn{2}{|r|}{ Jurassic } & $\begin{array}{l}\text { Upper (Late) } \\
\text { Middle (Middle) } \\
\text { Lower (Early) } \\
\end{array}$ & $-190-195$ \\
\hline & \multicolumn{2}{|r|}{ Triassic } & $\begin{array}{l}\text { Upper (Late) } \\
\text { Middle (Middle) } \\
\text { Lower (Early) }\end{array}$ & 225 \\
\hline \multirow{7}{*}{ Paleozoic } & \multicolumn{2}{|r|}{ Permian } & $\begin{array}{l}\text { Upper (Late) } \\
\text { Lower (Early) }\end{array}$ & 280 \\
\hline & \multirow{2}{*}{ 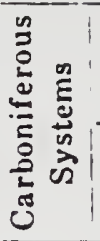 } & Pennsylvanian & $\begin{array}{l}\text { Upper (Late) } \\
\text { Middle (Middle) } \\
\text { Lower (Early) } \\
\end{array}$ & \\
\hline & & Mississippian & $\begin{array}{l}\text { Upper (Late) } \\
\text { Lower (Early) }\end{array}$ & 345 \\
\hline & \multicolumn{2}{|r|}{ Devonian } & $\begin{array}{l}\text { Upper (Late) } \\
\text { Middle (Middle) } \\
\text { Lower (Early) }\end{array}$ & 395 \\
\hline & \multicolumn{2}{|r|}{ Silurian } & $\begin{array}{l}\text { Upper (Late) } \\
\text { Middle (Middle) } \\
\text { Lower (Early) } \\
\end{array}$ & $-430-440$ \\
\hline & \multicolumn{2}{|r|}{ Ordovician } & $\begin{array}{l}\text { Upper (Late) } \\
\text { Middle (Middle) } \\
\text { Lower (Early) }\end{array}$ & .500 \\
\hline & \multicolumn{2}{|r|}{ Cambrian } & $\begin{array}{l}\text { Upper (Late) } \\
\text { Middle (Middle) } \\
\text { l.ower (Early) } \\
\end{array}$ & 570 \\
\hline \multicolumn{3}{|c|}{ I'recambrian } & $\begin{array}{l}\text { Informal subdivisions } \\
\text { iuch as upper midlle, } \\
\text { and luwer, or upper } \\
\text { and lower or younte- } \\
\text { er and oldier may be } \\
\text { used locally. }\end{array}$ & $3,+100+$ \\
\hline \multicolumn{5}{|c|}{ 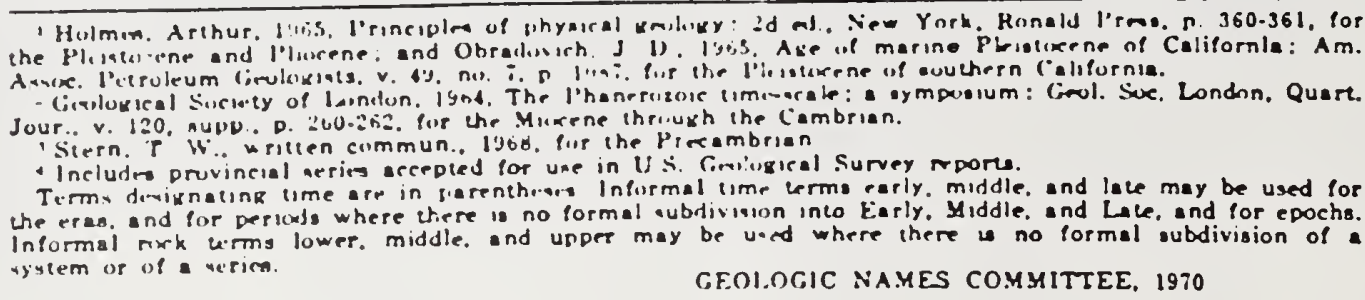 } \\
\hline
\end{tabular}


-

-

c 